\title{
THE OPTIMIZATION TECHNIQUES USED IN SOLAR DRYERS: A REVIEW
}

\section{MANISH JOSHI ${ }^{1}$, Dr. NEERAJ KUMAR ${ }^{2} \&$ Dr. PRASHANT BAREDAR ${ }^{3}$}

${ }^{I}$ Research Scholar, Suresh GyanVihar University, Jaipur, Rajasthan, India

${ }^{2}$ Professor, Department of Mechanical Engineering, Suresh GyanVihar University, Jaipur, Rajasthan, India

${ }^{3}$ Professor, Department of Energy, Maulana Azad National Institute of Technology (MANIT), Bhopal, India

\section{ABSTRACT}

The energy from the sun is the most important source comprising renewable energy available on earth. The utilization of solar radiation for fruitful results are done in almost all the sectors such as industries, automobiles, preserving food items, electricity production etc. Solar dryers are one such device which utilizes solar energy to generate heat for drying food items of different kinds. Solar dryer's effectiveness might be enhanced and developed by optimizing the parameters of solar dryers with suitable techniques. The present research depicts the review on a number of categories of solar dryers enhanced and studied that are used in the present days along with different optimizing techniques used such as Taguchi, ANOVA, GA etc. Works done in optimization by several scholars used in order to dry out moisture content from different edible items such as mushrooms, fish, chillies etc. are discussed in this paper. Few of the techniques used in the optimization of the solar dryer which were mostly used by previous authors are discussed in the present paper. The paper also includes discussion regarding the utilization of Particle Swarm Optimization (PSO) technique for the same purpose.

KEYWORDS: Solar Energy, Solar Dryers, Optimizing, Taguchi, ANOVA \& PSO

Received: Apr 20, 2019; Accepted: May 11, 2019; Published: Jun 17, 2019; Paper Id.: IJMPERDAUG20199

\section{INTRODUCTION}

The consumption of energy derived from solar source in reference to implementation at low temperature for the purpose of industries as well as commercial sector is growing globally and it is assumed to be the single most favorable regions so as to have the application as well as implementation regarding the energy form from the sun(Janjai, et al, 2011)(Prakash \& Kumar, 2014). Anxieties related to emissions of gas from green house (GHG) which results in rapid degradation of fossil based fuels, along with the process of drying appearing to be focused and concentrated energy, has marked the growth and enhancement of framework regarding drying dependent on the solar energy form at the level of industries (Luna, Nadeau, \& Jannot, 2009)(Pirasteh, Saidur, Rahman, \& Rahim, 2014).

Solar drying can be performed under the direct sunlight and under effect of green house. The energy of solar retained in the drying chamber is reliant on the time in hours of sunlight, climatic and atmospheric conditions as well as location (Ekechukwu' et.al', 1997).

A solar dryer is normally utilized in regions which get direct radiations from the sun for long time periods in the day time. The drying chamber is generally built from $1 \mathrm{~cm}$ thick wood which is pressed form to get the shape and it is provided with padding insulation of glass wool from the back side, inner side and the bottom of the walls. The inclined front wall is packed in a thick sheet of glass to permit radiation of sun to pass through. This 
transparent wall might be layered by an opaque coating and provided with sheets of insulation for the indirect mode of application of dryers. There is an exhaust outlet provided at the back face side of the dryer from which humid air is blown out with help of a small fan. At the lower section of the front wall it is made differently so as to get the redirection regarding the air which has higher temperature comprising from the accumulation of solar within the chamber area of the dryer by the means of centrifugal type blower (S. Janjai \& Bala, 2012)

\section{ARRANGEMENTOF SOLAR DRYERS}

The availability of solar dryers is in different designs and sizes and are mostly used to dry fruits and agricultural based products. Different types of dryers are accessible depending on the requirement from commercial areas to residential or household areas. On primary basis the entire solar dryers are categorized with reference to their temperature of operation which is high and low temperature solar dryers. (Nutalapati, 2013).

Equipment of drying might be categorized in various ways. The most utilized categories are (1) the process of heat transfer to moist objects that are solids(2) or the supervision features and properties that are physical comprising the material that is wet. The initial process of categorization exposes the variations in the design of the dryer and operation; on the other hand the later process is mostly utilized within the assortment comprising multiple number of dryers for initial presumptionsrelated to drying in the provided issue. (Belessiotis \& Delyannis, 2011)

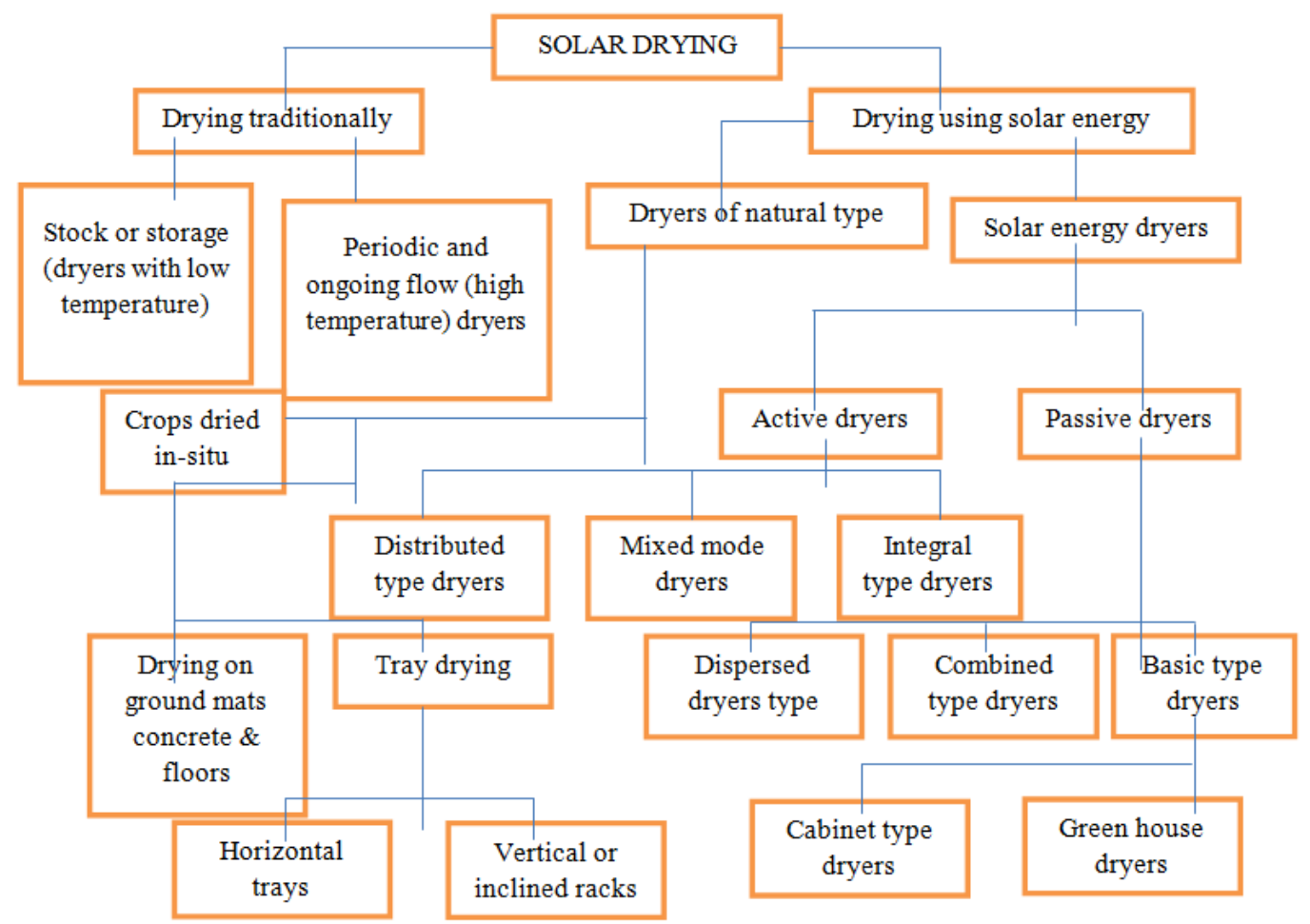

Figure 1: Classification of Solar Dryers

The 3 varying sub categories comprised of passive type or active type of system based on solar drying might be determined as(Leon, Kumar, \& Bhattacharya, 2002):

- Solar based dryers in reference to direct type category;

- solar based dryers with respect to indirect type category; and 
- $\quad$ solar based dryers comprised within hybrid form

(Leon et al., 2002)observed that these variables importantly impact the effectiveness of the dryer, they are:

- features of air used for drying (temperature of air used for drying, rate comprising flow of air as well as humidity);

- variables comprising the items or products (product's throughput, content quantity of moisture at the initial in addition with the final stage, size of the product and the dispersion of the size); and

- $\quad$ arameters for dimensions (length as well as width, in addition with its diameter or the height comprising the dryer, also including the specifications of the dryer and associated passes)

\section{OPTIMIZATION OF SOLAR DRYERS}

The evaluation as well as calibration of performance of solar based dryer comprises of the following parameters which were investigated by(Leon et al., 2002). The assortment regarding any dryer presents a concession in the cost of the dryer, its quality, concerns related to safety and methods in setting up the dryer. Nevertheless, the solar based dryers are limited and additionally they bear restriction which includes the working of the complete apparatus only when there is presence of the sun. This can be resolved by storing the extra energy all around the peak time of the day and then utilize the same at night time (Eustache, 2017). Also, when there is a low drying temperature, the process of drying is a process which is concentrated on energy and it impacts the workability as well as performance regarding the solar based dryers at degraded temperatures. Hence optimization of solar dryers is required to improve the performance of drying.

\section{OVERVIEW}

\section{Different Optimization Techniques used in Solar Drying}

At the time when it is in reference to solar based drying; the active modelling of features of drying regarding the food items and agro products, utilizing optimization techniques for instance, artificial intelligence procedures which includes genetic algorithms as well as neural network and have got attention, since the machine learning capability of a neural network is applicable in order to recognize the responses from fruits and plants, which are generally a complex method to which numerical or mathematical approaches are not implemented easily. Researches have been carried out to find out nonlinear and hard to explain the behavior of system with the help of neural networks and were performed in drying grain samples (Farkas, Reményi, \& Biró, 2000).(Khazaei, Chegini, \& Bakhshiani, 2008) conducted optimization on a solar dryer and used slices of tomatoes as the drying material. LSD (least significant difference) test was used along with Grey Prediction to calculate the results.

Several optimization techniques are used by researchers in optimizing solar dryers. Most common methods used are discussed below:

- Genetic Algorithm (GA) performs simulations in the process of optimization and hence calibrates optimum values for objective functions. Genetic Algorithm is the most widely used methods of optimization in order to get optimal values for objective functions by simulation of biological process based evolution process, similar to genetics, over mutation and crossover (Sharma, Garg, \& Kumar, 2018). The GA method was utilized to optimize solar dryer tunnel with red chillies as the drying material (Dhumne, Vipin Bipte, \& Jibhkate, 2016) 
- Taguchi is an optimization technique as well as a tool for design of experiments (DOE). This method is generally applied to obtain optimal set of values and it efficiently declines the number of turn for the experimental research. The optimization is carried out from set of matrix formation of the input parameters such as L9, L27 etc. Taguchi based approach was implemented to find the optimum extraction conditions in order to dry products of ginger so as to create oil at the end, which comprises of enhanced yield value. The regulating factors involved the reaction stage with respect to time, temperature needed for drying, detainment of pressure and additionally size of the particles of the powdered ginger (H. Chen, Chung, Wang, \& Huang, 2011).

- Fuzzy logic systems comprises of a former based data knowledge which is dependent on the protocols and is altered to a mode based on quantitative aspect permitting the requirement to implement regulated planning comprised of multivariate that are primary as well as effortlessly comprehended by users. The plus point of fuzzy logic have inspired research fields so as to utilize fuzzy logic in addition with control systems in engineering as well as industrial methods, so as to enhance and improve the efficiency of the processes compared to that of conventional systems. (Vásquez, Reyes, Mahn, \& Cubillos, 2016). The principle of fuzzy logic was implemented in drying process in a solar dryer using $15 \mathrm{~kg}$ of peach as the dataset and the resultant moisture was decreased to $31 \%$ in the final output. (J. Vásquez et al., 2016).

- ANOVA (analysis of variance) is utilized to figure out the percent of participation of each of the input parameters considered so as to optimize any solar dryer. The variance values observed in a specific variable are divided in to categories attributable to several variation sources in the method of ANOVA (Esen \& Turgut, 2015). (Tasirin et al., 2013) conducted drying process in solar dryer and used peels of orange fruit as the dataset. The solar dryer was a fluidized bed type dryer and method of Taguchi was applied. Then after, ANOVA method was used which showed that ratio of skin peels of orange fruit to quantity mass of sand was overriding involvement and crucial factor regarding the content of the moisture including the parameter of velocity as well as temperature with respect to air.

Here are some of the previous works done by several scholars in optimizing the performance of solar dryers using different optimizing techniques and statistical models along with different types of food and agricultural items as data set.

Table 1: Research Done by Previous Researchers in Optimization of Solar Dryers

\begin{tabular}{|c|l|l|l|l|}
\hline Year & \multicolumn{1}{|c|}{ Author Name } & \multicolumn{1}{|c|}{ Technique used } & \multicolumn{1}{c|}{ Data Set } & \multicolumn{1}{c|}{$\begin{array}{c}\text { Moisture Content } \\
\text { Obtained }\end{array}$} \\
\hline 1 & $\begin{array}{l}\text { (Obayopo \& Alonge, } \\
2018)\end{array}$ & $\begin{array}{l}\text { Analysis of Variance } \\
\text { (ANOVA) }\end{array}$ & $\begin{array}{l}\text { Catfish } \\
\text { (Clariasgariepinus) } \\
\text { and tilapia fish } \\
\text { (Oreochromisniloticus }\end{array}$ & $\begin{array}{l}\text { Maximum dried } \\
\text { moisture obtained was } \\
74.3 \%\end{array}$ \\
\hline 2 & $\begin{array}{l}\text { (Padmanaban \& Palani, } \\
2017)\end{array}$ & $\begin{array}{l}\text { Taguchi Method \& Grey } \\
\text { Relational Analysis with } \\
\text { COPRA }\end{array}$ & Grains & $\begin{array}{l}\text { Moisture left is 37.36\% } \\
\text { and 32.28 \% }\end{array}$ \\
\hline 3 & $\begin{array}{l}\text { (Salvatierra-Rojas, Nagle, } \\
\text { Gummert, de Bruin, \& } \\
\text { Müller, 2017) }\end{array}$ & $\begin{array}{l}\text { (ANOVA). Evaluations } \\
\text { of means were carried out } \\
\text { by Duncan's Multiple } \\
\text { Range Test }\end{array}$ & Paddy rice & $\begin{array}{l}\text { Moisture removal } \\
\text { reached 57.7\% after } \\
\text { shade drying }\end{array}$ \\
\hline 4 & $\begin{array}{l}\text { (Ndukwu \& Bennamoun, } \\
2017)\end{array}$ & $\begin{array}{l}\text { Analysis of Variance } \\
\text { (ANOVA) }\end{array}$ & Red chilli & $\begin{array}{l}\text { Sodium Sulfate } \\
\text { Decahydrate 7.6-10\%. } \\
26.7 \% \text { and 39\% in } \\
\text { contrast regarding drying } \\
\text { usingNaCl }\end{array}$ \\
\hline
\end{tabular}




\begin{tabular}{|c|c|c|c|c|}
\hline 5 & (N., Tidke, \& N, 2016) & $\begin{array}{l}\text { (ANOVA) as well as } \\
\text { Post-hoc Tukey's test } \\
\text { was implemented within } \\
\text { the study }\end{array}$ & Fish & $\begin{array}{l}\text { Reduction in moisture } \\
\text { content from } 80 \% \text { to } \\
15 \%\end{array}$ \\
\hline 6 & (Dhumne et al., 2016) & $\begin{array}{l}\text { Genetic Algorithm (GA) } \\
\text { approach }\end{array}$ & Red chilies & $\begin{array}{l}\text { Moisture removed } \\
45.49 \%\end{array}$ \\
\hline 7 & $\begin{array}{l}\text { (Monteiro, Carciofi, \& } \\
\text { Laurindo, 2016) }\end{array}$ & $\begin{array}{l}\text { Software toolStatistical } \\
7.0 \text { (StatSoft,), in } \\
\text { addition with (ANOVA) }\end{array}$ & Banana & $\begin{array}{l}\text { Moisture from the } \\
\text { Samples were removed } \\
\text { by MWVD and } \\
\text { MWMFD } \\
\text { depicteddegradations of } \\
26-27 \% \text { and } 33-36 \%\end{array}$ \\
\hline 8 & $\begin{array}{l}\text { (Zebib, Teame, \& Meresa, } \\
\text { 2017) }\end{array}$ & $\begin{array}{l}\text { Two way analysis of } \\
\text { variance (ANOVA) }\end{array}$ & Tilapia fish & Moisture loss (\%) 79.54 \\
\hline 9 & (Vásquez et al., 2016) & $\begin{array}{l}\text { Predictive fuzzy logic } \\
\text { control system }\end{array}$ & $\begin{array}{l}\text { Peach Drying, } \\
\text { Mushroom Drying, } \\
\text { Plum Drying }\end{array}$ & $\begin{array}{l}\text { Moisture reduced by } \\
88 \%\end{array}$ \\
\hline 10 & $\begin{array}{l}\text { (Khama, Aissani, \& } \\
\text { Alkama, 2016) }\end{array}$ & $\begin{array}{l}\text { Analysis of Variance } \\
\text { (ANOVA) }\end{array}$ & Tomato & $\begin{array}{l}\text { Moisture reduced by } \\
66.56 \%\end{array}$ \\
\hline 11 & (Agrawal, 2015) & $\begin{array}{l}\text { Analysis of Variance } \\
\text { (ANOVA) }\end{array}$ & Peas & $\begin{array}{l}\text { The moisture reduced by } \\
81 \%(\mathrm{wb}) \text { or } 426.2 \% \\
\text { (db) respectively }\end{array}$ \\
\hline 12 & $\begin{array}{l}\text { (Hubackova, Kucerova, } \\
\text { Chrun, Chaloupkova, \& } \\
\text { Banout, 2014) }\end{array}$ & $\begin{array}{l}\text { ANOVA and Fisher's } \\
\text { LSD test. }\end{array}$ & Fish & $\begin{array}{l}\text { Moisture reduced by } \\
73.12 \% \text { and } 77.82 \%\end{array}$ \\
\hline 13 & $\begin{array}{l}\text { (Reyes, Cubillos, Mahn, } \\
\text { \& Vásquez, 2014) }\end{array}$ & $\begin{array}{l}\text { Controller of fuzzy logic } \\
\text { sufficientlyregulated } \\
\text { therate of air flow }\end{array}$ & Mushrooms & $\begin{array}{l}\text { Moisture content } \\
\text { reduced from } 93 \% \text { to } 6 \%\end{array}$ \\
\hline 14 & (Rahman \& Billah, 2014) & Genetic Algorithm (GA) & Mushroom & $\begin{array}{l}\text { Moisture reduced by } \\
73 \%\end{array}$ \\
\hline 15 & $\begin{array}{l}\text { (Hegde, Hosur, Rathod, } \\
\text { Harsoor, \& Narayana, } \\
\text { 2015) }\end{array}$ & Genetic Algorithm (GA) & Banana & $\begin{array}{l}\text { Moisture reduced by } \\
75 \%\end{array}$ \\
\hline 16 & $\begin{array}{l}\text { (Munusami \& Dinesh, } \\
\text { 2013) }\end{array}$ & $\begin{array}{l}\text { Black body radiation } \\
\text { principle }\end{array}$ & Fish & $\begin{array}{l}\text { Moisture reduced about } \\
25 \%\end{array}$ \\
\hline 17 & $\begin{array}{l}\text { (Jadhav, Visavale, Sutar, } \\
\text { Annapure, \& Thorat, } \\
\text { 2013) }\end{array}$ & $\begin{array}{l}\text { Surface methodology } \\
\text { optimization using } \\
\text { ANOVA }\end{array}$ & $\begin{array}{l}\text { Green Peas } \\
\text { (Pisumsativum) }\end{array}$ & $\begin{array}{l}\text { Moisture reduced by } \\
(80 \%) \text {. }\end{array}$ \\
\hline 18 & $\begin{array}{l}\text { (Tasirin, Puspasari, Xing, } \\
\text { Yaakob, \& Ghani, 2013) }\end{array}$ & $\begin{array}{l}\text { Analysis of Variance } \\
\text { (ANOVA) }\end{array}$ & Oranges & $\begin{array}{l}\text { Moisture content }(\mathrm{g} / \mathrm{g} \\
\mathrm{db}) 1.0968\end{array}$ \\
\hline 19 & $\begin{array}{l}\text { (H. H. Chen, Chung, Hsu, } \\
\text { \& Huang, 2010) }\end{array}$ & $\begin{array}{l}\text { Grey Analysis and } \\
\text { Analysis of variance } \\
\text { (ANOVA) }\end{array}$ & Pineapple & $\begin{array}{l}\text { Moisture removed by } \\
80 \%\end{array}$ \\
\hline 20 & (Khazaei et al., 2008) & $\begin{array}{l}\text { Least significant } \\
\text { difference (LSD) test }\end{array}$ & Tomatoes & $\begin{array}{l}\text { Moisture reduced by } \\
75 \%\end{array}$ \\
\hline
\end{tabular}

Few of the other works from various scholars on optimization of solar dryers based on moisture content left after applying the optimization method.

Table 2: Different Optimization Techniques used to Minimize the Final Moisture Content Left

\begin{tabular}{|l|l|l|c|}
\hline \multicolumn{1}{|c|}{ Authors } & \multicolumn{1}{|c|}{ Optimization Method } & \multicolumn{1}{c|}{ Type of Solar Dryer } & $\begin{array}{c}\text { Output } \\
\text { Moisture Left }\end{array}$ \\
\hline $\begin{array}{l}\text { (Macías-ganchozo et } \\
\text { al., 2018) }\end{array}$ & $\begin{array}{l}\text { linear regression and } \\
\text { variance }\end{array}$ & Mixed mode solar drier & $10.35 \%$ \\
\hline (Vásquez et al., 2016) & fuzzy logic control system & Open type direct solar dryer & $55 \%$ \\
\hline (Reyes et al., 2014) & fuzzy logic controller & Hybrid Solar Dryer & $6 \%$ \\
\hline
\end{tabular}




\begin{tabular}{|l|l|l|c|}
\hline $\begin{array}{l}\text { (H. H. Chen et al., } \\
\text { 2010) }\end{array}$ & $\begin{array}{l}\text { Grey model and Analysis of } \\
\text { variance (ANOVA) }\end{array}$ & $\begin{array}{l}\text { Solar energy-assisted photo } \\
\text { catalyst low-pressure dryer } \\
\text { (SEPLD) }\end{array}$ & $5.9 \%$ \\
\hline (Khazaei et al., 2008) & $\begin{array}{l}\text { Least significant difference } \\
\text { (LSD)\& ANN model }\end{array}$ & Indirect type solar dryer & $15 \%$ \\
\hline
\end{tabular}

\section{SWARM OPTIMIZATION (PARTICLE SYSTEM)}

In the year of 1995, the authors Kennedy as well as Eberhart presented the concept of Particle swarm optimization (PSO) together. PSO represents a multivariable technique for computation which is dependent on the intelligence parameters with regards to swarm; for instance communal behavior and efficiency comprising livestock animals, flock of birds, group of fishes, a bee swarm and even related to human behavior prospects. Although, PSO is configured comprising of population of swarm regarding random solutions related to fitness function which are closely linked to genetic algorithm but PSO does not conduct mutation or crossover process as found in GA. (Guangyou, Dingfang, \& Guozhu, 2007). The result outcomes within the PSO is termed as particles in the swarm which obtain the value for the function that is best comprising the fitness aspect in the provided region or space. Each of the particle has its self-memory, which aids in identifying the most suitable and best solution that is possible in that given space or region, which is also referred to as personal-best (Pbest). The velocities are updated for every swarm particle which functions less in order to explore nevertheless exploit in PSO function. The optimizer of the swarm particle takes another best value, when entire population are its topological neighbours, the best value attained for the complete swarm is known as global best (Gbest) (Siddhartha, Sharma, \& Varun, 2012)

Most of the time the concept of PSO is used in optimizing shape, size etc of any allied structure, identification of system in biomechanics and optimization of power dispersion of electrical networks. (Cuturi \& Fukumizu, 2007). PSO technique has a great potential and has wide range in optimizing in several sectors including engineering and industries. MATLAB tool is often used in the application of PSO through programming and codes. It simulates the input variables and shows the optimized results accordingly. However, PSO is not commonly used to optimize solar devices such as solar dryers. Although it could be implemented for the same with proper input variables.

\section{CONCLUSIONS}

In the present study, a review of optimization techniques used in drying systems based on solar energy has been carried out. The most basic area regarding implementation dryers based on solar energy is in the sector of farming and drying of agricultural products. Among the various optimization techniques reviewed in this paper Analysis of Variance (ANOVA) is most widely and successfully applied techniques for modelling the solar drying processes. In addition with, these methods might be implemented to several kinds of processes comprising basic alterations in the specifications. Moreover, prior to utilization of the framework regarding solar drying on huge scale, methods for optimization should be incorporated to identify the optimum configuration of variables that impact the effectiveness and working of the drying systems. Optimization techniques such as particle swarm optimization (PSO) can be utilized in order so as to optimize those variables of solar dryers. Since PSO has wide range of functions in optimization in several areas and almost negligible work is done by previous authors and investigators in implementing the particle swarm optimization technique in the field of solar dryers. 


\section{REFERENCES}

1. V. EKECHUKWU'* and B. NORTON'. (1997). Experimental Studies of Integral-Type Solar-Energy Tropical. Elsevier Science Ltd., 8904(14), 1483-1500.

2. Agrawal, A. K. (2015). Solar Drying of Pea: Comparison of Various Methods Considering Its Dehydration and Rehydration Characteristics. International Journal of Research Studies in Biosciences (IJRSB), 0357(August), 83-88.

3. Belessiotis, V., \& Delyannis, E. (2011). Solar drying. Solar Energy, 85(8), 1665-1691. https://doi.org/10.1016/j.solener.2009.10.001

4. Chen, H., Chung, C., Wang, H., \& Huang, T. (2011). Application of Taguchi Method to Optimize Extracted Ginger Oil in Different Drying Conditions. International Conference on Food Engineering and Biotechnology, 9, 310-316.

5. Chen, H. H., Chung, C. C., Hsu, C. H., \& Huang, T. C. (2010). Application of grey prediction in a solar energy-assisted photocatalytic low-pressure drying process. Drying Technology, 28(9), 1097-1106.

https://doi.org/10.1080/07373937.2010.506168

6. Cuturi, M., \& Fukumizu, K. (2007). Kernels on structured objects through nested histograms. Advances in Neural Information Processing Systems 19 (NIPS 2006), 329-336. https://doi.org/10.1109/CEC.2001.934374

7. Dhumne, L. R., Vipin Bipte, E. H., \& Jibhkate, Y. M. (2016). Optimization of Solar Tunnel Dryer Using Genetic Algorithm. International Research Journal of Engineering and Technology, 2395-56.

8. Esen, H., \& Turgut, E. (2015). Optimization of operating parameters of a ground coupled heat pump system by Taguchi method. Energy and Buildings, 107, 329-334. https://doi.org/10.1016/j.enbuild.2015.08.042

9. Eustache, H. (2017). Design and Optimization of Domestic Solar Dryer. Science Journal of Energy Engineering, 5(6), 130. https://doi.org/10.11648/j.sjee.20170506.11

10. Farkas, I., Reményi, P., \& Biró, A. (2000). A neural network topology for modelling grain drying. Computers and Electronics in Agriculture, 26(2), 147-158. https://doi.org/10.1016/S0168-1699(00)00068-5

11. Guangyou, Y., Dingfang, C., \& Guozhu, Z. (2007). A Modified Particle Swarm Optimizer Algorithm 3 The Modified Particle Swarm Optimizer Algorithm ( MPSO ), 1. https://doi.org/1-4244-1135-1/07/\$25.00

12. Hegde, V. N., Hosur, V. S., Rathod, S. K., Harsoor, P. A., \& Narayana, K. B. (2015). Design, fabrication and performance evaluation of solar dryer for banana. Energy, Sustainability and Society, 5(1). https://doi.org/10.1186/s13705-015-0052-x

13. Hubackova, A., Kucerova, I., Chrun, R., Chaloupkova, P., \& Banout, J. (2014). Development of Solar Drying Model for Selected Cambodian Fish Species. Scientific World Journal, 2014. https://doi.org/10.1155/2014/439431

14. Jadhav, D. B., Visavale, G. L., Sutar, N., Annapure, U. S., \& Thorat, B. N. (2013). Drying Technology: An International Journal Studies on Solar Cabinet Drying of Green Peas ( Pisum sativum) Studies on Solar Cabinet Drying of Green Peas ( Pisum sativum ). Drying Technology: An International Journal, (August 2013), 37-41.

https://doi.org/10.1080/07373931003788064

15. Janjai, S., \& Bala, B. K. (2012). Solar Drying Technology. Food Engineering Reviews, 4(1), 16-54. https://doi.org/10.1007/s12393-011-9044-6 
16. Janjai, S., Intawee, P., Kaewkiew, J., Sritus, C., \& Khamvongsa, V. (2011). A large-scale solar greenhouse dryer using polycarbonate cover: Modeling and testing in a tropical environment of Lao People's Democratic Republic. Renewable Energy, 36(3), 1053-1062. https://doi.org/10.1016/j.renene.2010.09.008

17. Khama, R., Aissani, F., \& Alkama, R. (2016). Design and performance testing of an industrial-scale indirect solar dryer. Journal of Engineering Science and Technology, 11(9), 1263-1281.

18. Khazaei, J., Chegini, G. R., \& Bakhshiani, M. (2008). A novel alternative method for modeling the effects of air temperature and slice thickness on quality and drying kinetics of tomato slices: Superposition technique. Drying Technology, 26(6), 759775. https://doi.org/10.1080/07373930802046427

19. Leon, M. A., Kumar, S., \& Bhattacharya, S. C. (2002). A comprehensive procedure for performance evaluation of solar food dryers. Renewable and Sustainable Energy Reviews, 6(4), 367-393. https://doi.org/10.1016/S1364-0321(02)00005-9

20. Luna, D., Nadeau, J. P., \& Jannot, Y. (2009). Solar timber kilns: State of the art and foreseeable developments. Renewable and Sustainable Energy Reviews, 13(6-7), 1446-1455. https://doi.org/10.1016/j.rser.2008.08.017

21. Macías-ganchozo, E. R., Bello-moreira, I. P., Trueba-macías, S. L., Enrique, X., Anchundia-muentes, M. E., \& Bravo-moreira, C. D. (2018). Design, development and performance of solar dryer for pineapple ( Ananas comosus ( L .) Merr .), mamey ( Mammea americana L .) and banana (Musa paradisiaca L .) fruit drying. Agroindustry and Food Science, 67, 30-38.

22. Monteiro, R. L., Carciofi, B. A. M., \& Laurindo, J. B. (2016). A microwave multi-flash drying process for producing crispy bananas. Journal of Food Engineering, 178, 1-11. https://doi.org/10.1016/j.jfoodeng.2015.12.024

23. Munusami, A., \& Dinesh, K. K. (2013). Performance Analysis of Solar Drying System for Marine Product. International Journal of Students Research in Technology \& Management, 1(06), 610-613.

24. N., N., Tidke, V., \& N, T. B. (2016). Microbial and biochemical analysis of dried fish and comparative study using different drying methods. Drying Technology, 35(12), 1480-1491.

25. Ndukwu, M. C., \& Bennamoun, L. (2017). Potential of integrating Na 2 SO 4 . $10 H 2$ O pellets in solar drying system Potential of integrating Na2SO4 . $10 \mathrm{H} 2 \mathrm{O}$ pellets in solar drying system. Drying Technology, 3937(August). https://doi.org/10.1080/07373937.2017.1366506

26. Nutalapati, S. (2013). International journal of engineering research online a peer reviewed international journal, (November). Retrieved from

https://www.researchgate.net/publication/309609622_STUDY_ON_THE_FIBRE_REINFORCED_CONCRETE_USING_STE EL_SLAG_AS_THE_COARSE_AGGREGATE_REPLACEMENT

27. Obayopo, S. O., \& Alonge, O. I. (2018). Development and Quality Analysis of a Direct Solar Dryer for Fish. Food and Nutrition Sciences, 09(05), 474-488. https://doi.org/10.4236/fns.2018.95037

28. Padmanaban, G., \& Palani, P. K. (2017). Grey Relation Analysis of Solar Drying Process Parameter on Copra. Ital. J. Food Sci, 29, 434-442.

29. Phoungchandang, S., Nongsang, S., Sanchai, P., Phoungchandang, S., Nongsang, S., \& Sanchai, P. (2013). Drying Technology: An International Journal The Development of Ginger Drying Using Tray Drying, Heat Pump - Dehumidified Drying, and Mixed-Mode Solar Drying The Development of Ginger Drying Using Tray Drying, Heat Pump - Dehumidified Drying, and Mixe. Drying Technology: An International Journal, (June 2013), 37-41.

https://doi.org/10.1080/07373930903221424 
30. Kumar, R. S. Latent Heat Storage Material Evaluation base on AHP and TOPSIS for Low Temperature Solar Heating Applications.

31. Pirasteh, G., Saidur, R., Rahman, S. M. A., \& Rahim, N. A. (2014). A review on development of solar drying applications. Renewable and Sustainable Energy Reviews, 31, 133-148. https://doi.org/10.1016/j.rser.2013.11.052

32. Prakash, O., \& Kumar, A. (2014). Solar greenhouse drying: A review. Renewable and Sustainable Energy Reviews, 29, $905-$ 910. https://doi.org/10.1016/j.rser.2013.08.084

33. Rahman, M. M., \& Billah, A. G. M. M. (2014). Application of Genetic Algorithm for optimization of Solar Powered Drying. IEEE Innovative Smart Grid Technologies - Asia (ISGT ASIA) Application, 647-651.

34. Reyes, A., Cubillos, F., Mahn, A., \& Vásquez, J. (2014). Dehydration of Agro Products in a Hybrid Solar Dryer Controlled through a Fuzzy Logic System. International Journal of Modern Nonlinear Theory and Application, 3(3), 66-76. https://doi.org/10.4236/ijmnta.2014.33009

35. Reyes, A., Mahn, A., Cubillos, F., \& Huenulaf, P. (2013). Ener gy Conversion and Man agement Mushroom dehydration in a hybrid-solar dryer. Energy Conversion and Management, 70, 31-39. https://doi.org/10.1016/j.enconman.2013.01.032

36. Salvatierra-Rojas, A., Nagle, M., Gummert, M., de Bruin, T., \& Müller, J. (2017). Development of an inflatable solar dryer for improved postharvest handling of paddy rice in humid climates. International Journal of Agricultural and Biological Engineering, 10(3), 269-282. https://doi.org/10.3965/j.ijabe.20171003.2444

37. Sharma, N., Garg, A., \& Kumar, S. (2018). An overview of optimization techniques used in solar drying. Asian Journal of Science and Appelied Technology (AJSAT), (May).

38. Siddhartha, Sharma, N., \& Varun. (2012). A particle swarm optimization algorithm for optimization of thermal performance of a smooth flat plate solar air heater. Energy, 38(1), 406-413. https://doi.org/10.1016/j.energy.2011.11.026

39. Tasirin, S. M., Puspasari, I., Xing, L. J., Yaakob, Z., \& Ghani, J. A. (2013). Energy optimization of fluidized bed drying of orange peel using taguchi method. World Applied Sciences Journal, 26(12), 1602-1609.

https://doi.org/10.5829/idosi.wasj.2013.26.12.1655

40. Kassem, T. K., Alosaimy, A., Fazian, M., \& Hamed, A. M. (2013). Development of the solar kilns used in drying the palm trees waste in Saudi Arabia. Int. J. Mech. Eng, 2(2), 43-50.

41. Vásquez, J., Reyes, A., Mahn, A., \& Cubillos, F. (2016). Experimental evaluation of fuzzy control solar drying with thermal energy storage system. Drying Technology, 34(13), 1558-1566. https://doi.org/10.1080/07373937.2015.1137001

42. Zebib, H., Teame, T., \& Meresa, T. (2017). Evaluation of solar dryers on drying and sensory properties of salted Tilapia filets, Tigray, Northern Ethiopia. ISABB Journal Of Food And Agriculture Science, 7(2), 10-18. https://doi.org/10.5897/ISABBJFAS2017.0065 
